\title{
Effect of Formaldehyde Inhalation on the Structure of Cerebellar Cortex of Adult Male Albino Rats
}

\author{
Original \\ Article \\ Mary Refaat Isaac ${ }^{l}$ and Shereen Adel Saad ${ }^{2}$ \\ ${ }^{1}$ Anatomy and Embryology Department, ${ }^{2}$ Assistant Professor of Anatomy and Embryology \\ Department, Faculty of Medicine, Ain Shams University, Cairo, Egypt
}

\begin{abstract}
Introduction: Formaldehyde (FA) exposure is a widely growing worldwide problem. It is not only confined to outdoor occupational exposure but extends indoors owing to the domestic use of multiple FA containing materials. Many FA induced neurological adverse effects have been reported. The cerebellum, being a part of the nervous system responsible for coordination, fine movements and motor learning, thus its affection may cause hazardous effects.

Aim of work: to study the effect of FA exposure on the cerebellar cortical tissue and the possible reversibility of these effects upon withdrawal.

Materials and methods: thirty adult male albino rats, aging 4-6 months and weighing $200-250$ gms, were used in this study. Animals were divided equally into three groups; Group I: control group. Group II: subjected to $10 \%$ FA inhalation for 8 hours/day, 6 days/week for four weeks. Group III: subjected to FA inhalation for the same duration as group II then left for another four weeks without exposure. At the end of the experiment for each group, specimens were collected and processed for light and electron microscopic examination and morphometric studies.

Results: Examination of sections of group II revealed significant decrease in thickness of both molecular and granular layers. Purkinje layer showed multiple focal areas of loss, dark irregular cells with highly significant decrease in diameter and marked ultrastructural abnormalities. However, group III showed insignificant increase in thickness of molecular and granular layers. Purkinje layer exhibited irregular alignment of cells, areas of focal loss and others with multi-layering. Purkinje neurons varied widely in shape, size and ultrastructural findings with insignificant increase in their mean diameter. Increased neuroglial cells was also noted in groups II and III.

Conclusion: Formaldehyde inhalation might cause irreversible insult to the cerebellar cortex, thus avoidance or limitation of exposure is highly recommended.
\end{abstract}

Received: 30 August 2018, Accepted: 02 September 2018

Key Words: Cerebellum, exposure, formaldehyde,recovery.

Corresponding Author: Mary Refaat Isaac, Anatomy and Embryology Department, Faculty of Medicine, Ain Shams University, Cairo, Egypt, Tel.: +20 1001171964, E-mail: drmaryrefaat@yahoo.com

ISSN: $1110-0559$, Vol. 41, No. 4

\section{INTRODUCTION}

Formaldehyde (FA) is a widely spread chemical compound that is vastly used nowadays in both outdoor as well as indoor environments. In industry, it is widely used in plastics, insulators, dyes, textiles, rubbers, cables and wood industries. In medicine; it is found among dental coating materials, drug preservatives, hospital sterilization chemicals in addition to its popular use in fixation of cadavers and tissues. Astonishingly, FA is also present in deodorants, toothpaste, ink, paper and cosmetic products ${ }^{[1]}$.

Therefore, FA exposure is not confined to a specific category of people as might be thought, but on the contrary, everyone might be highly exposed to it. Effects of FA exposure vary from mere irritation up to carcinogenesis.
Some researchers reported that longtime contact with FA may cause irritation of the eye and upper respiratory tract ${ }^{[2]}$. On the other hand, The International Agency for Research on Cancer has classified FA as a human carcinogen, which causes certain cancers such as nasopharyngeal cancer ${ }^{[3]}$ and leukemia ${ }^{[4]}$. This could be attributed to the fact that it rapidly reacts with DNA and RNA proteins leading to detrimental effects on human health ${ }^{[5]}$.

However, previous studies have reported its neurological adverse effects. Among these effects were; headache, dizziness, sleep disorders, memory loss ${ }^{[6]}$ together with evident decline in locomotor activity and obvious neurotoxic effects ${ }^{[7]}$. Since the cerebellum plays a key role in coordination, fine movements as well as motor 
learning, its damage may lead to impairment of balance, fine movement, posture ${ }^{[8]}$ as well as cognitive function ${ }^{[9]}$. However, some studies were concerned about the harmful effects of FA on cerebellar cortex and tried to find effective protective compounds including selenium ${ }^{[10]}$ in an attempt to reduce these harmful FA induced effects.

On the other hand, regarding the effect of duration of FA exposure, some studies reported that, exposure to FA can cause irreversible neurotoxicity up to brain cancer on the long run ${ }^{[1]}$.

However, whether possible FA induced cerebellar damage are reversible or not has not been yet established. Therefore, the aim of the present work was to study the effect of FA inhalation on the cerebellar cortex of adult male albino rats and the possible reversibility of these effects upon FA withdrawal.

\section{MATERIALS AND METHODS}

\section{Animals:}

Thirty adult male albino rats, aging 4 - 6 months and weighing 200 - $250 \mathrm{gms}$, were obtained from the Animal House of the Bilharzial Research Unit, Ain Shams University. Animals were housed in conventional wiremesh cages, $72 \mathrm{~cm} \times 36 \mathrm{~cm} \times 44 \mathrm{~cm}$ in dimensions, in a regulated room temperature about $21 \pm 10^{\circ} \mathrm{C}$, humidity 45 $50 \%$, and light/dark cycles. Rats were fed on standard rat diet and allowed free access to water. They were allowed to acclimatize to experimental conditions by housing them for 10 days prior to the experiment. All animal procedures conform the requirements of our institutional Animal Research and Ethics Committee.

Drugs: Formaldehyde 10\% concentration solution was brought from El NASR pharmaceutical chemicals Company, Egypt.

\section{Experimental protocol:}

Animals were equally divided into three groups as follows:

Group I (Control Group): It was composed of 10 adult male albino rats. They were not subjected to any treatment.

Group II (Exposure Group): It included 10 adult male rats subjected to formaldehyde inhalation released from a cotton piece placed in a small glass box inside the cages and soaked with $10 \%$ FA solution. . The cotton piece was replaced every one hour to keep a constant concentration. These animals were subjected to formaldehyde inhalation 8 hours/day ${ }^{[11]}$. This was done for 6 days/week for four weeks.

Group III (Recovery Group): It included 10 adult male rats subjected to FA inhalation in the same way as group II. After this period of exposure, rats were left for another four weeks without FA exposure in an attempt for recovery.
At the end of the experiment, all rats were anaesthetized using ether inhalation. The cerebella were dissected out Specimens of right cerebellum were processed for both paraffin, semithin and ultrathin sections to be examined by the light and electron microscopes.

For light microscopic studies, mid sagittal sections of the cerebella were cut and specimens with $5 \times 5 \mathrm{~mm}$ thickness were immersed in $10 \%$ FA in distilled water for one week. After fixation, tissues were dehydrated in ascending grades of ethanol, cleared in xylol and embedded in paraffin blocks. Sections of $5 \mu \mathrm{m}$ in thickness were cut and stained with Haematoxylin and Eosin (Hx. and E.) Stain ${ }^{[12]}$. The sections were examined with an Olympus light microscope and photographed.

For electron microscopic studies, specimens were immediately cut into cubes ( $1 \mathrm{~mm}$ in diameter) and fixed overnight in $2.5 \%$ phosphate-buffered glutaraldehyde $(\mathrm{pH} 7.3)$ at $4^{\circ} \mathrm{C}$. Specimens were then postfixed in $1 \%$ buffered osmium tetroxide for 1-2 hrs, dehydrated in ascending grades of ethyl alcohol, cleared in propylene oxide, and finally embedded in fresh Epon blocks. Semithin sections $1 \mu \mathrm{m}$ in thickness were cut with glass knives on LKB ultramicrotome and stained with $1 \%$ toluidine blue with $\mathrm{pH} 7.3^{[13]}$. Sections were then examined by an Olympus light microscope to choose the selected areas. Ultrathin sections, $50-80 \mathrm{~nm}$, were cut from selected areas of the blocks on a Reichert ultramicrotome, placed on copper grids and contrasted with uranyl acetate and lead citrate $^{[13]}$. These sections were prepared and examined in the transmission electron microscope unit, Faculty of Science Ain Shams University.

Morphometric analysis was carried out on routine Hx. and E. stained slides using image analyzer Leica Q win V.3 program installed on a computer in the Histology Department, Faculty of Medicine, Ain Shams University. The computer was connected to a Leica DM2500 microscope (Wetzlar, Germany). Five specimens from five different rats of each group were examined. For each specimen, four different captured non-overlapping high-power fields $(\times 20)$ were taken to measure the thickness of both molecular and granular layers together with the diameter of Purkinje neurons. Data analysis was performed using MedCalc ${ }^{\circledR}$ Version 11.1.1.0 for Windows (MedCalc Software, Belgium) and Microsoft Office Excel 2010 (Microsoft, USA) where Analyses Of Variance (ANOVA test), mean, standard deviation (SD) and T-test were done. $T$ test result was considered to be highly significant when $\mathrm{P} \leq 0.001$, significant when $\mathrm{P} \leq 0.05$ and insignificant when $\mathrm{P}>0.05$.

\section{RESULTS}

\section{(A) Histological Results:}

\section{Group I (Control Group):}

Histological examination of cerebellar sections of the control group stained with Hx. and E revealed that the cerebellar cortex was composed of three distinct layers 
namely; molecular, Purkinje and granular cell layers (Fig. 1). The outer molecular layer contained superficial stellate cells and inner basket cells. Purkinje cells were aligned in one row, typically piriform in shape with arborizing dendrites arising from their apices and their cytoplasm studded with Nissel's granules and having central open face nuclei. The granular layer was composed of more densely packed granule cells with deeply stained nuclei and Golgi type II cells, these cells were separated by acellular areas (cerebellar islands) (Fig. 2).

Semithin sections showed piriform Purkinje neurons with arborizing dendrites, vesicular nuclei and prominent nucleoli. They were aligned along the outer margin of the granular cell layer (Fig. 3).

Ultrathin sections further clarified the detailed structure of the Purkinje neurons which appeared almost pear shaped with a smooth contour surrounded by tight and full neuropil (Fig. 4). The cytoplasm was clear and rich in mitochondria, Golgi apparatus, rough endoplasmic reticulum (rER) and free ribosomes (Fig. 5). A likewise homogenous nucleoplasm bounded by a regular nuclear membrane with almost no indentations (Fig. 4) and a dense, prominent nucleolus was observed (Figs. 4 and 5). Granule cells showed their characteristic rounded heterochromatic nuclei surrounded by a shell of cytoplasm containing strands of $\mathrm{rER}$, free ribosomes and mitochondria. Intervening neuroglial cells and myelinated nerve fibers containing mitochondria were also observed (Fig. 6).

\section{Group II (Exposure Group):}

Histological examination of the cerebellar cortical tissue of rats exposed to FA inhalation revealed the appearance of pyknotic nuclei in the molecular layer (Fig.7). Purkinje cell layer revealed severely affected focal areas with almost complete absence of neurons (Figs 7 and 8). Some cells were shrunken irregular with no visible Nissel's granules in their cytoplasm (Fig. 9) and appeared surrounded by empty neuropil (Figs.7 and 9). Neuropils enclosing pyknotic nuclei were also seen (Fig. 9). Granular layer showed many areas of apparent focal decrease in thickness (Fig. 8). Clumping of its cells was also regularly encountered (Figs. 7 and 9). Moreover, some Purkinje neurons were sometimes seen encroaching on the granular layer or even found deeper in the vicinity of its cells (Fig. 8).

Semithin sections revealed marked irregularity in the shape and variability in the size of Purkinje neurons. However, the cytoplasm of the majority of them was deeply stained with hardly identified nuclei or nucleoli. Glial cells were also observed in the vicinity of those degenerated neurons. Clumping of granular cells was seen in some areas (Fig. 10).

Ultrathin sections revealed numerous Purkinje neurons with shrunken, crenated cell membrane from which filiform appendages originate (Fig. 11). Cytoplasm was obviously darkened containing mitochondria with ruptured cristae and markedly dilated, irregularly arranged cisterns of rER with scanty ribosomal granules (Figs. 11 and 12) together with some vacuolar spaces (Fig. 12). Nucleus appeared markedly irregular with crenated nucleolemma and disturbance in chromatin distribution (Fig. 11). These obviously dystrophic Purkinje neurons were also surrounded by loose vacuolar semi confluent interstitial spaces representing significant loss of the texture of the neuropil (Figs. 11 and 12). Moreover, many granule cells with pyknotic nuclei were seen among others with almost normal ones whose nuclei were surrounded by a shell of cytoplasm with scanty organelles. Adjacent heterogeneous neuroglial cells were frequently observed (Fig. 13).

\section{Group III (Recovery Group):}

Histological examination of the cerebellar cortical tissue of rats exposed to FA for four weeks and left to recover for another four weeks revealed that the molecular layer still exhibited few pyknotic nuclei (Fig. 14). Purkinje layer showed areas of irregularly alignment and multilayering of Purkinje neurons together. Few neighboring ones showed focal loss (Fig. 15) which were however relatively narrower and less frequently observed compared to the exposure group. Many Purkinje cells appeared irregular in shape and surrounded by empty neuropil (Figs. 14, 15 and 16). Few appeared rarified with almost complete degeneration (Fig. 16). However, scattered rounded to almost piriform shaped Purkinje cells some of which with open face nuclei and others with visible dendrites were also observed. Reduction in Nissel's granules was observed in cytoplasm of Purkinje cells. As for granular layer neurons, most of them appeared scattered and others appeared retaining their clumped arrangement (Fig. 16).

Semithin sections revealed Purkinje neurons with variable sizes, shapes and degrees of degeneration. Persistence of many irregular deeply stained Purkinje with hardly identified nuclei was detected. Shrunken ones with irregular nuclei and very pale stained cytoplasm surrounded by a vacuolated halo were also encountered. Glial cells were seen near the degenerated Purkinje neurons (Fig. 17).

Ultrathin sections further clarified the variability in the Purkinje neuronal shape and size. Some of which appeared with almost regular contour containing heterochromatic nuclei with regular nucleolemma but with no visible nucleoli (Fig. 18). It was surrounded by pale stained cytoplasm (Fig. 18) with rER, ribosomes and mitochondria (Figs. 18 and 19) with ill-defined outline (Fig. 19). Others appeared with almost autolyzed pyknotic nuclei (Fig. 20) surrounded by a more electron dense cytoplasm studded with dark rounded lysosomes (Figs. 20 and 21), some mitochondria and rER (Fig. 21). Areas of vacuolation were observed surrounding many Purkinje neurons and dispersed in the interstitial space (Figs. 18, 19 and 20). Granule cells appeared with their characteristic heterochromatic nuclei but the surrounding shell of cytoplasm showed many vacuolar spaces and some mitochondria with ruptured cristae ${ }^{[22]}$. Some intervening neuroglial cells were also encountered (Fig. 20). 


\section{(B) Morphometric Results:}

Using morphometric studies, in the control group, the mean thickness of molecular layer, that of the granular layer and the mean diameter of Purkinje neurons were measured and their values were mentioned in tables 1,2 and 3 respectively.

In group II, both molecular layer (Table 1) and granular one (Table 2) showed highly significant decrease in thickness. Mean Purkinje neuronal diameter also showed a highly significant reduction (Table 3 ).

In group III, the molecular layer thickness showed non-significant increase compared to the exposure group, and still retaining a significant decrease compared to the control group (Table 1). Granular layer thickness showed a non-significant increase compared to the exposure group and a highly significant decrease than the control group level (Table 2). Similarly, Purkinje neuronal diameter increased yet this increase was insignificant compared to the exposure group and still highly significantly decreased when compared to the control group (Table 3 ).

Comparisons among the morphometric results of the three groups were further illustrated in the hereunder histograms (histograms 1, 2 and 3).

Table 1: comparing the thickness of Molecular Layer in Hx. andE. stained sections among the three groups showing $P$ value either; non-significant $(\Phi)$, significant $(*)$ or highly significant $(* *)$.

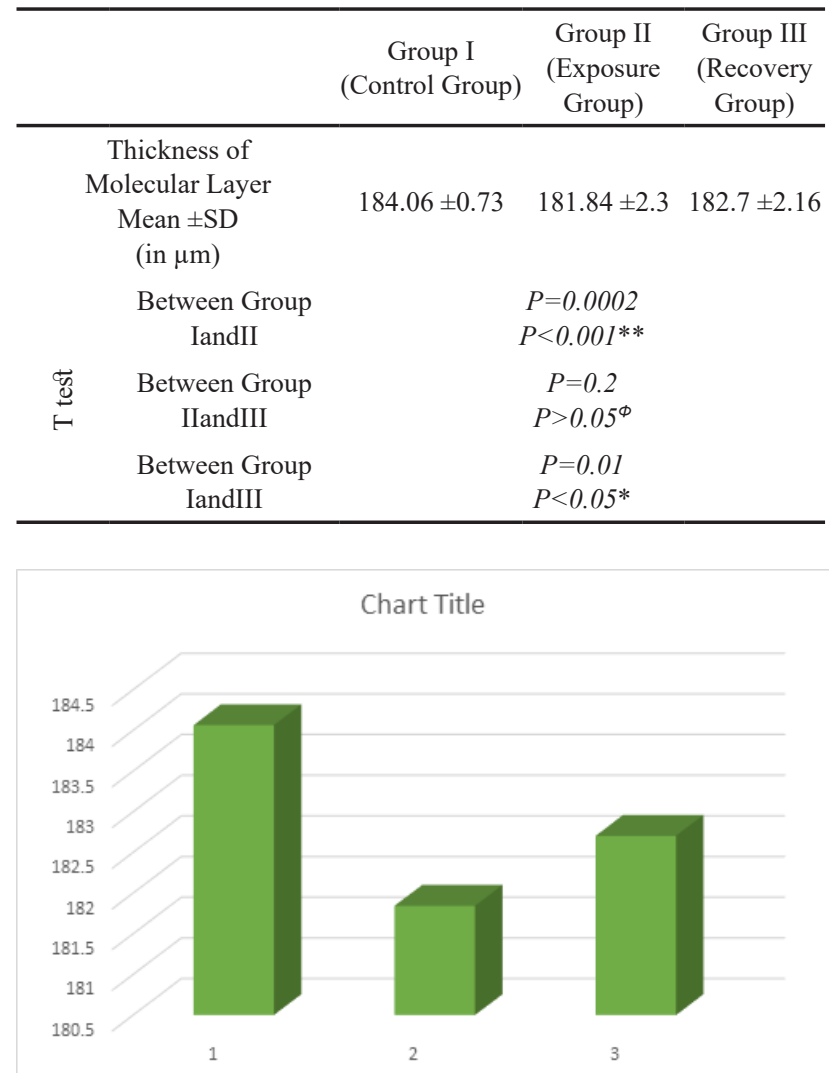

Histogram 1: Demonstrating the morphometric comparison between the three groups as regards; molecular layer thickness.
Table 2: comparing the thickness of Granular Layer in Hx. andE. stained sections among the three groups

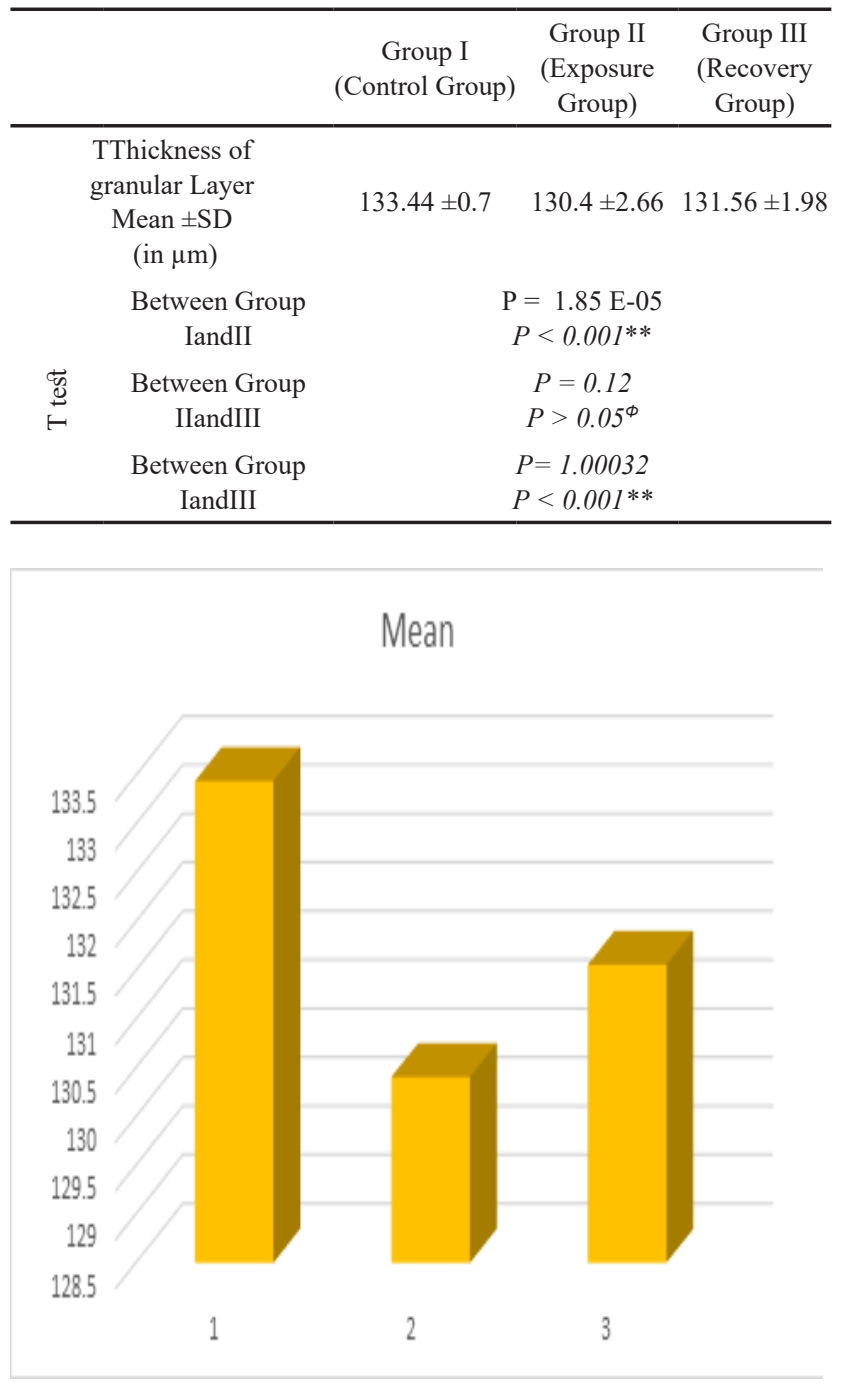

Histogram 2: demonstrating the morphometric comparison between the three groups as regards; Granular layer thickness.

Table 3: comparing the diameter of Purkinje neuron in $\mathrm{Hx}$. andE. stained sections among the three groups.

\begin{tabular}{|c|c|c|c|c|}
\hline & & $\begin{array}{c}\text { Group I } \\
\text { (Control Group) }\end{array}$ & $\begin{array}{c}\text { Group II } \\
\text { (Exposure } \\
\text { Group) }\end{array}$ & $\begin{array}{l}\text { Group III } \\
\text { (Recovery } \\
\text { Group) }\end{array}$ \\
\hline \multicolumn{5}{|c|}{ Diameter of Purkinje neuron } \\
\hline & $\begin{array}{l}\text { Mean } \pm \text { SD } \\
\text { (in } \mu \mathrm{m})\end{array}$ & $18.76 \pm 0.72$ & $13.65 \pm 1.89$ & $15.89 \pm 3.99$ \\
\hline \multirow{5}{*}{ 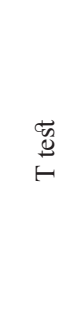 } & Between Group & \multicolumn{3}{|c|}{$P=1.046 E-13$} \\
\hline & IandII & \multicolumn{3}{|c|}{$P<0.001$ ** } \\
\hline & $\begin{array}{l}\text { Between Group } \\
\text { IIandIII }\end{array}$ & \multicolumn{3}{|c|}{$P=0.105$} \\
\hline & Between Group & \multicolumn{3}{|c|}{$P=0.00048$} \\
\hline & IandIII & \multicolumn{3}{|c|}{$P<0.001$ ** } \\
\hline
\end{tabular}




\section{Chart Title}

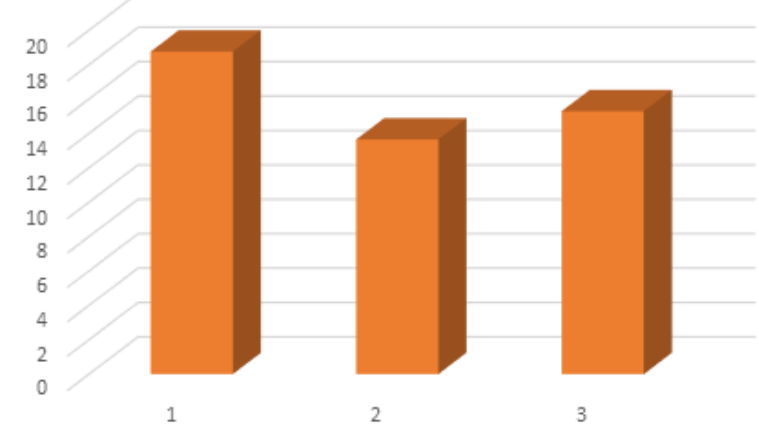

Histogram 3: demonstrating the morphometric comparison between the three groups as regards; Purkinje neuron diameter.

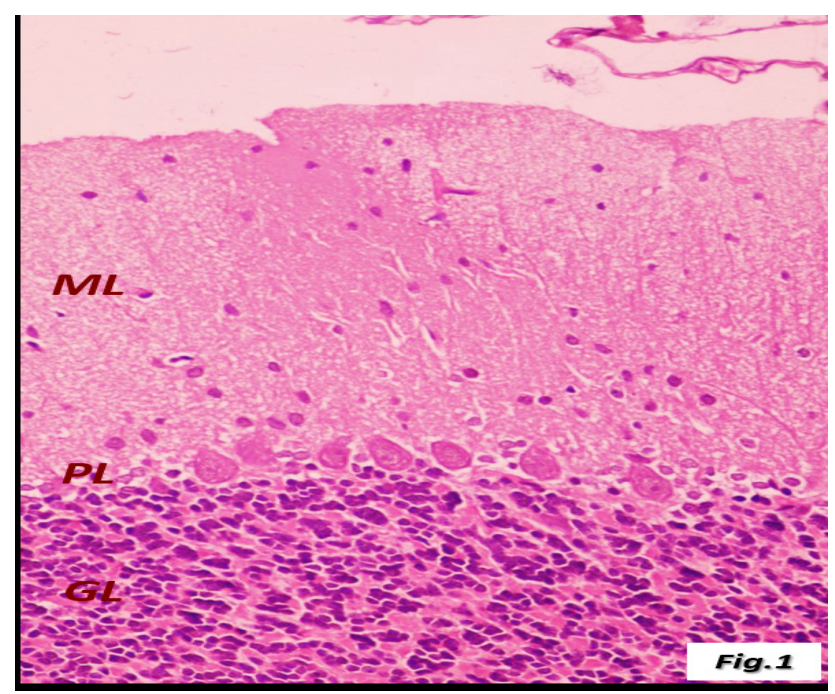

Fig. 1: A photomicrograph of a section of the cerebellar cortex of group I albino rat showing the cerebellar cortical layers; the molecular (ML), Purkinje (PL) and granular (GC) cell layers. (Hx. and E., x400)

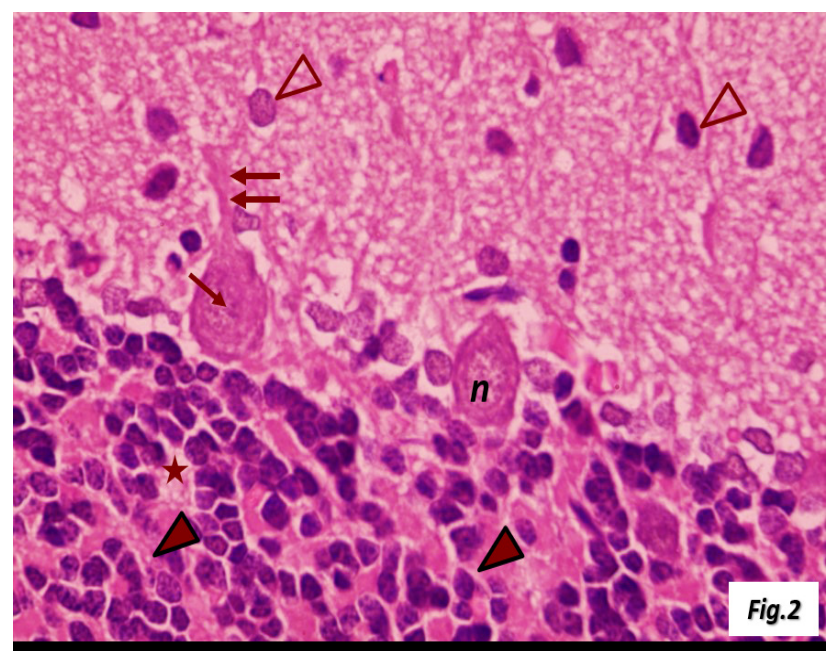

Fig. 2: A photomicrograph of a section of the cerebellar cortex of group I albino rat showing rounded to oval nuclei $(\Delta)$ in the molecular layer and more densely packed deeply stained nuclei $(\boldsymbol{\Delta})$ with cerebellar islands (*) in the granular layer. Note the interposed Purkinje layer with piriform Purkinje cells (P) having arborizing dendrite $(\uparrow \uparrow)$ and central open face nucleus (n) and Nissel's granules ( $\uparrow)$. (Hx. and E., x1000)

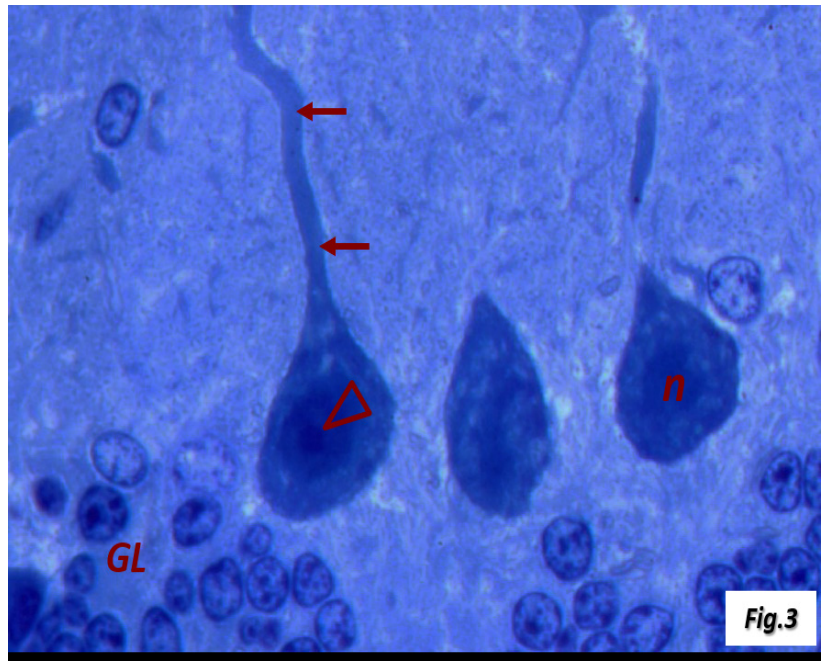

Fig. 3: A photomicrograph of a section of the cerebellar cortex of group I albino rat showing piriform Purkinje neurons aligned along the outer margin of the granular cell layer. Notice their vesicular nuclei (n), prominent nucleoli $(\boldsymbol{\Delta})$ and the arborizing dendrites $(\uparrow)$ (Toluidine blue, $\mathrm{x} 1000)$

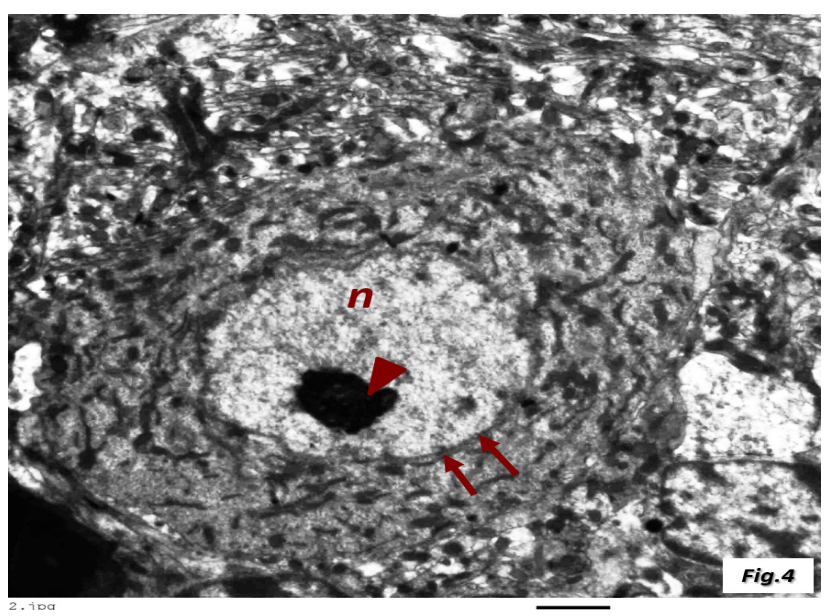

Fig. 4: A photomicrograph of a section of the cerebellar cortex of group I albino rat showing Purkinje neuron with smooth contour surrounded by tight and full neuropil. It has euchromatic nucleus (n) with prominent nucleolus $(\boldsymbol{\Delta})$. Notice the regular nuclear membrane $(\uparrow)$. (TEM x1500)

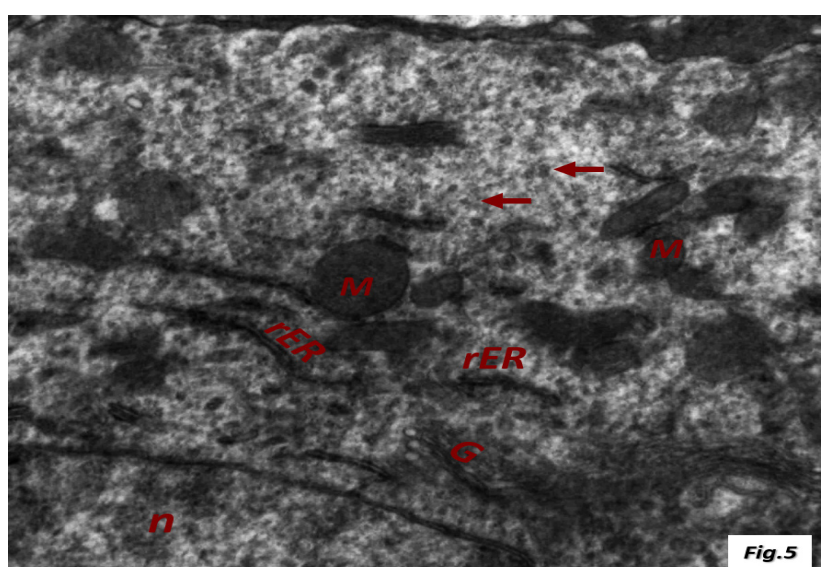

Fig. 5: A photomicrograph of a section of the cerebellar cortex of group I albino rat showing Purkinje neuron with clear cytoplasm, containing mitochondria (M), Golgi apparatus (G), rER (rER) and free ribosomes $(\uparrow)$. Notice also part of its nucleus (n). (TEM x7500) 


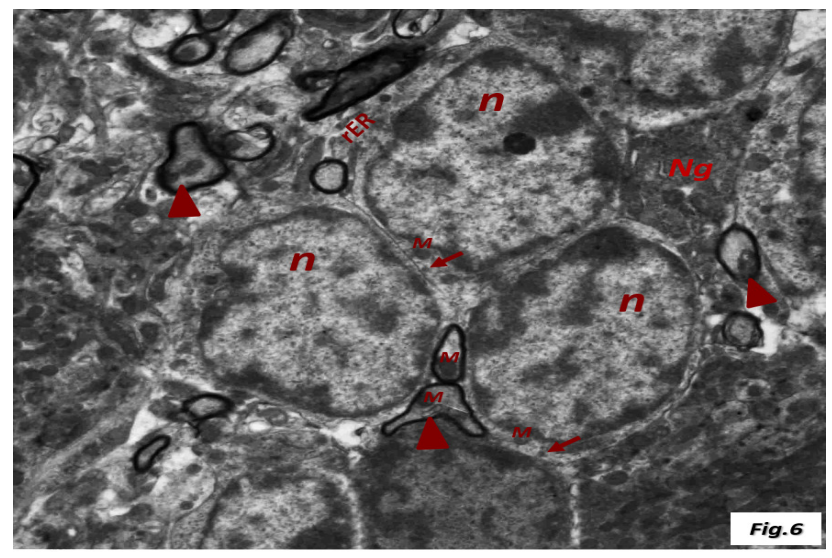

Fig. 6: A photomicrograph of a section of the cerebellar cortex of group I albino rat showing granule cells with rounded heterochromatic nuclei (n) and a surrounding shell of cytoplasm containing strands of rER (rER), free ribosomes $(\uparrow)$, and mitochondria $(\mathrm{M})$. Notice the neuroglial cells $(\mathrm{Ng})$ and the myelinated nerve fibers $(\boldsymbol{\Delta})$ containing mitochondria $(\mathrm{M})$. (TEM x2000)

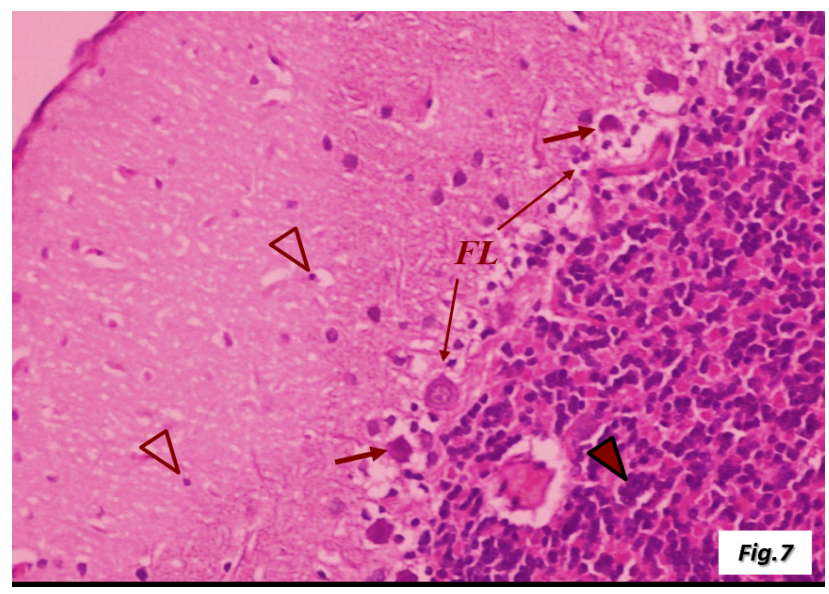

Fig. 7: A photomicrograph of a section of the cerebellar cortex of group II albino rat showing molecular layer containing pyknotic nuclei $(\Delta)$. Focal area of loss of neurons $(\leftarrow \mathrm{FL} \rightarrow$ ) is obvious in Purkinje cell layer. Most of the Purkinje cells are irregular, shrunken with empty neuropils $(\uparrow)$. Notice the clumped granule cells in the granular layer $(\boldsymbol{\Lambda})$. (Hx. and E., x400)

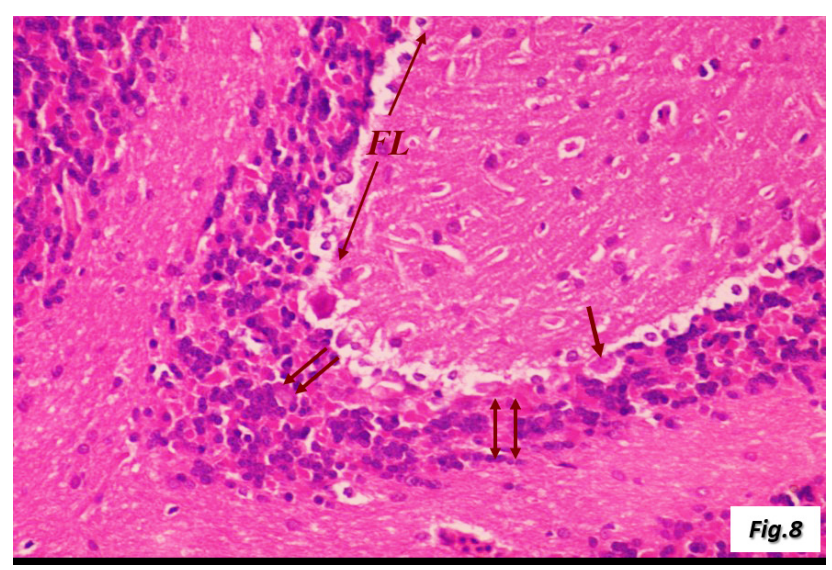

Fig. 8: A photomicrograph of a section of the cerebellar cortex of group II albino rat showing apparent decrease in thickness of the granular layer $(\uparrow \uparrow)$. Notice the Purkinje neuron encroaching on the granular layer $(\uparrow)$ and another one deeply situated in the same layer $(\uparrow \uparrow)$. Note also the areas of focal loss in the Purkinje cell layer $(\leftarrow \mathrm{FL} \rightarrow$ ). (Hx. and E., $\mathrm{x} 400)$

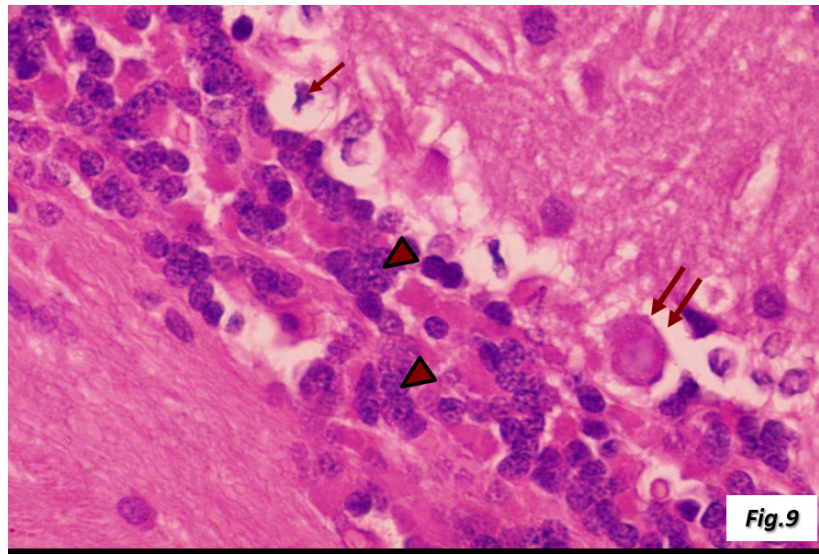

Fig. 9: A photomicrograph of a section of the cerebellar cortex of group II albino rat showing Purkinje neuron with empty neuropil ( $\uparrow \uparrow)$ with no Nissel's granules seen in their cytoplasm and adjacent neuropil enclosing pyknotic nucleus $(\uparrow)$. Notice the clumped granular cells $(\boldsymbol{\Delta})$. (Hx. and E., $x 1000)$

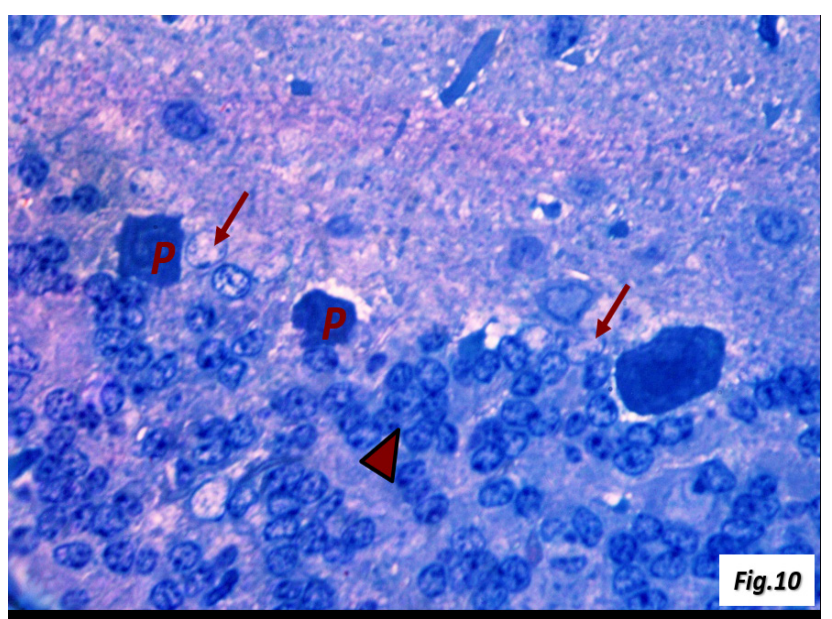

Fig. 10: A photomicrograph of a section of the cerebellar cortex of group II albino rat showing deeply stained irregular Purkinje neurons (P) with invisible nucleoli. No Nissel's granules are seen. Notice the glial cells $(\uparrow)$ in the vicinity of the Purkinje neurons. Clumping of cells $(\boldsymbol{\Delta})$ in the granular layer is obvious. (Toluidine blue, x1000)

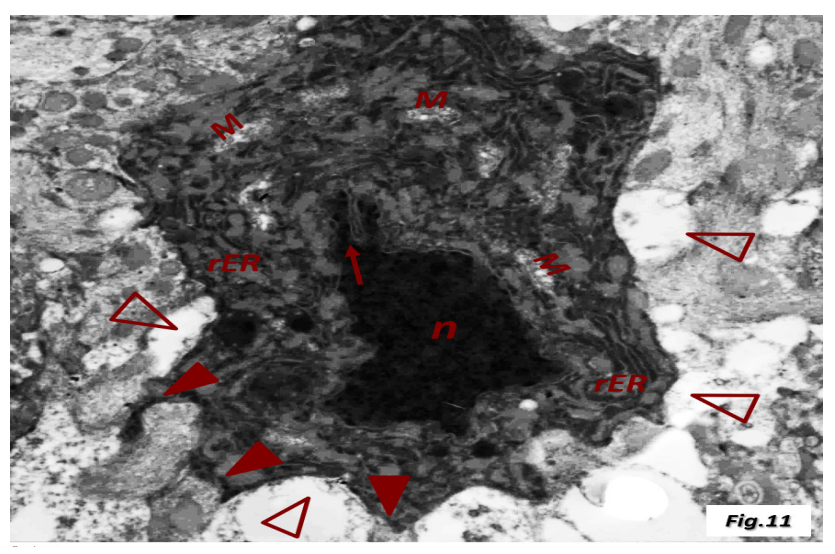

Fig. 11: A photomicrograph of a section of the cerebellar cortex of group II albino rat showing Purkinje neuron with crenated cell membrane having filiform appendages $(\boldsymbol{\Delta})$, dark cytoplasm with dilated cisterns of rER (rER) and mitochondria with ruptured cristae (M). Notice the irregular nucleus with disturbance in chromatin distribution (n) and crenated nucleolemma $(\uparrow)$. Note also the surrounding loose vacuolar spaces $(\Delta)$. (TEM x2000) 


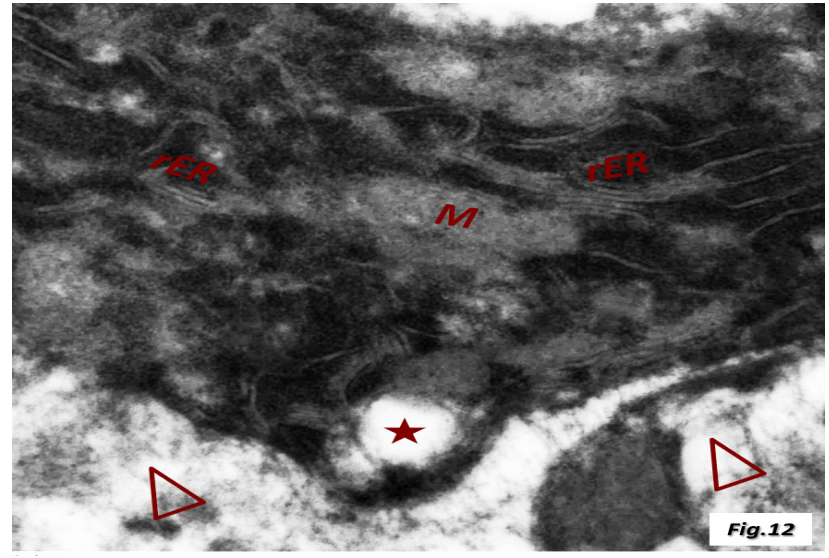

Fig. 12: A photomicrograph of a section of the cerebellar cortex of group II albino rat showing Purkinje neuron with dark cytoplasm containing vacuolar spaces $(*)$, mitochondria with ruptured cristae $(\mathrm{M})$ and dilated irregularly arranged cisterns of rER (rER) with sparse ribosomal granules. Notice the surrounding loose vacuolar spaces $(\Delta)$. (TEM x7500)

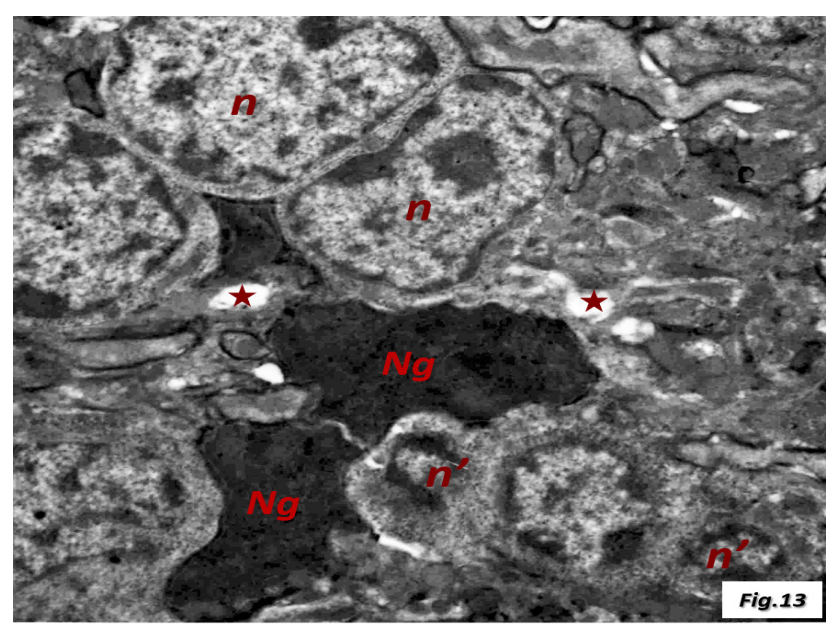

Fig. 13: A photomicrograph of a section of the cerebellar cortex of group II albino rat showing granule cells with pyknotic nuclei (n') are seen among others with almost normal ones (n). Notice the surrounding cytoplasmic shell with scanty organelles. Note also the adjacent heterogeneous neuroglial cells $(\mathrm{Ng})$ and the interstitial vacuolar spaces $\left(^{*}\right)$. (TEM x2000)

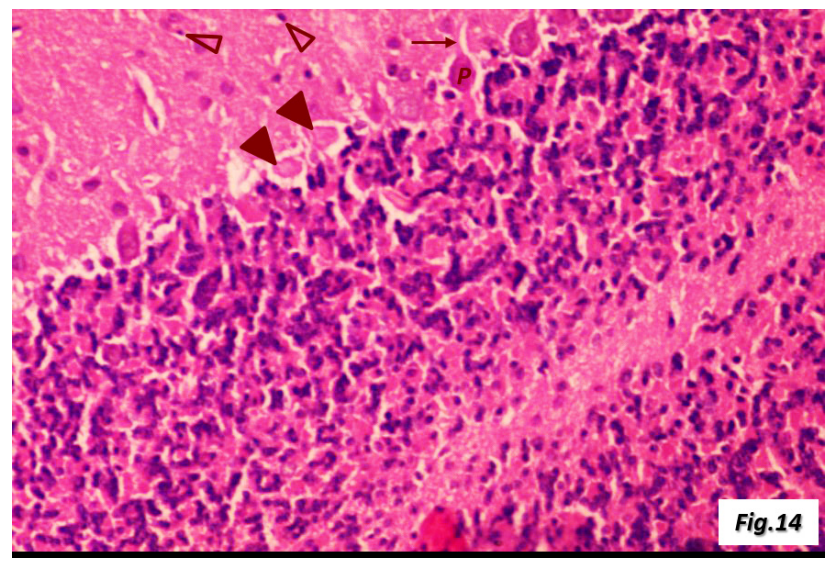

Fig. 14: A photomicrograph of a section of the cerebellar cortex of group III albino rat showing pyknotic nuclei in the molecular layer $(\Delta)$. Irregular shaped Purkinje neurons surrounded by empty neuropil $(\boldsymbol{\Delta})$ are seen. Notice the piriform shaped Purkinje (P) and the visible dendrite $(\uparrow)$. (Hx. and E., x400)

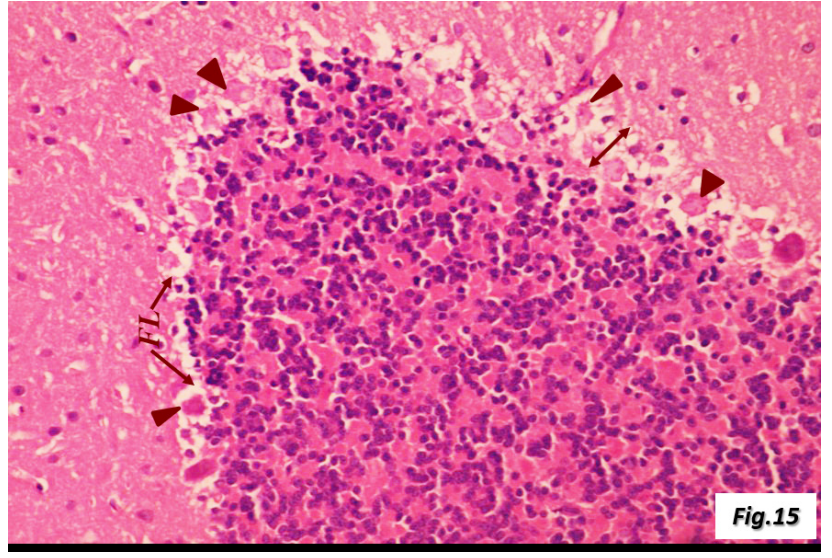

Fig. 15: A photomicrograph of a section of the cerebellar cortex of group III albino rat showing irregular alignment, multi layering $(\uparrow)$ and an area of focal loss $(\leftarrow \mathrm{FL} \rightarrow)$ of neurons in the Purkinje cell layer. Notice the irregularly shaped neurons with empty neuropils ( $\boldsymbol{\Delta}$ ). (Hx. and E., x400)

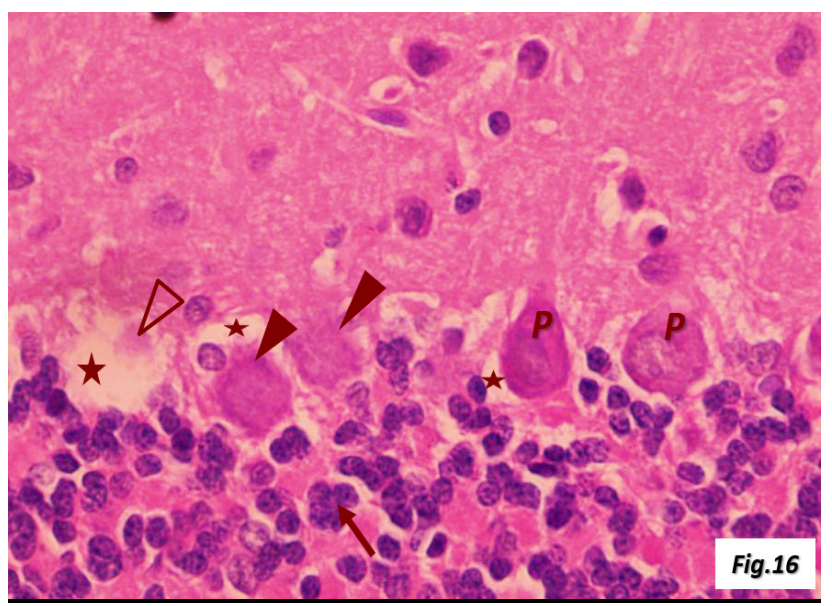

Fig. 16: A photomicrograph of a section of the cerebellar cortex of group III albino rat showing piriform and rounded Purkinje neurons with open face nuclei $(\mathrm{P})$, adjacent to irregular neurons $(\boldsymbol{\Delta})$. Others are completely rarified $(\Delta)$. Notice their empty neuropils $(*)$. Note also the clumped appearance $(\uparrow)$ of some granule cells (. (Hx. and E., x1000)

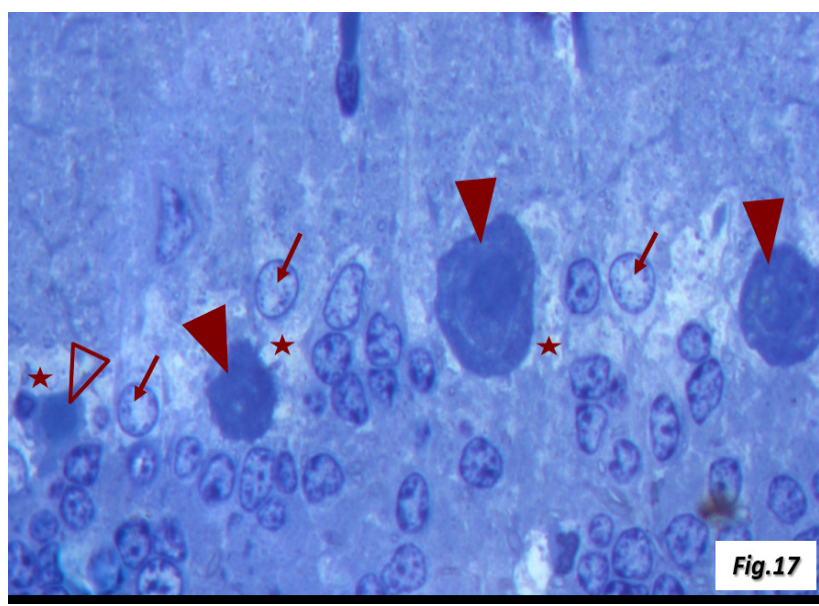

Fig. 17: A photomicrograph of a section of the cerebellar cortex of group III albino rat showing irregular deeply stained Purkinje neurons $(\boldsymbol{\Delta})$ with hardly identified nuclei and a pale stained shrunken one with irregular nucleus $(\Delta)$. Notice the empty neuropils $(*)$ of the Purkinje neurons and the nearby glial cells $(\uparrow)$. (Toluidine blue, $\mathrm{x} 1000)$ 


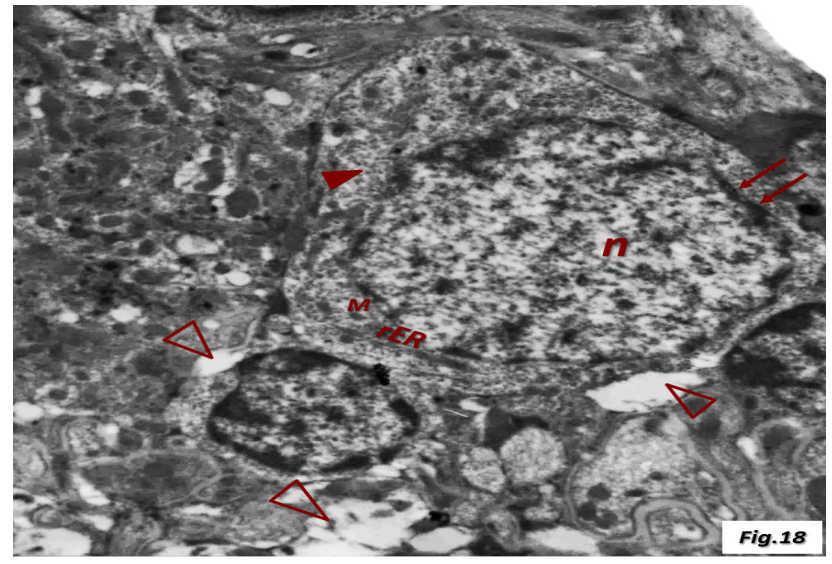

Fig. 18: A photomicrograph of a section of the cerebellar cortex of group III albino rat showing Purkinje neuron with almost regular contour containing heterochromatic nucleus (n) with regular nucleolemma $(\uparrow)$ but with no visible nucleoli surrounded by pale stained cytoplasm with visible rER (rER) and mitochondria (M). Notice the dispersed vacuolar spaces $(\Delta)$. (TEM x2000)

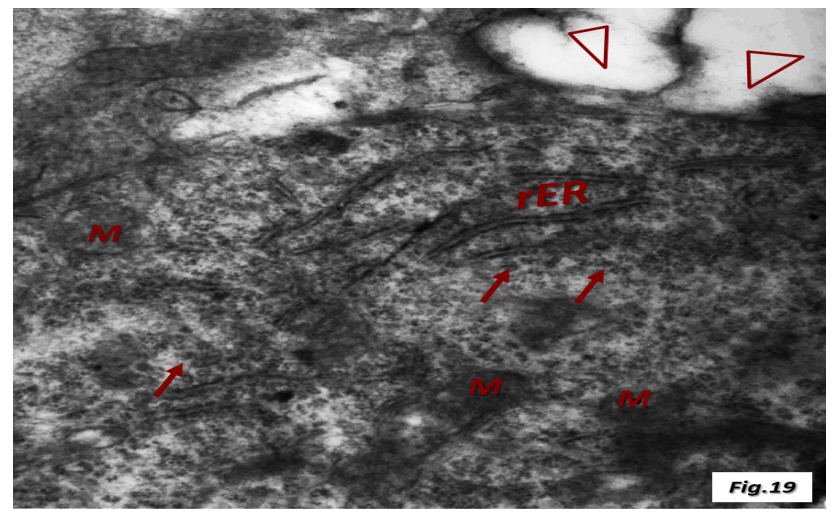

Fig. 19: A photomicrograph of a section of the cerebellar cortex of group III albino rat showing Purkinje neuronal cytoplasm with visible rER (rER), ribosomes $(\uparrow)$ and mitochondria with ill-defined outline (M). Notice the vacuolar spaces $(\Delta)$. (TEM x7500).

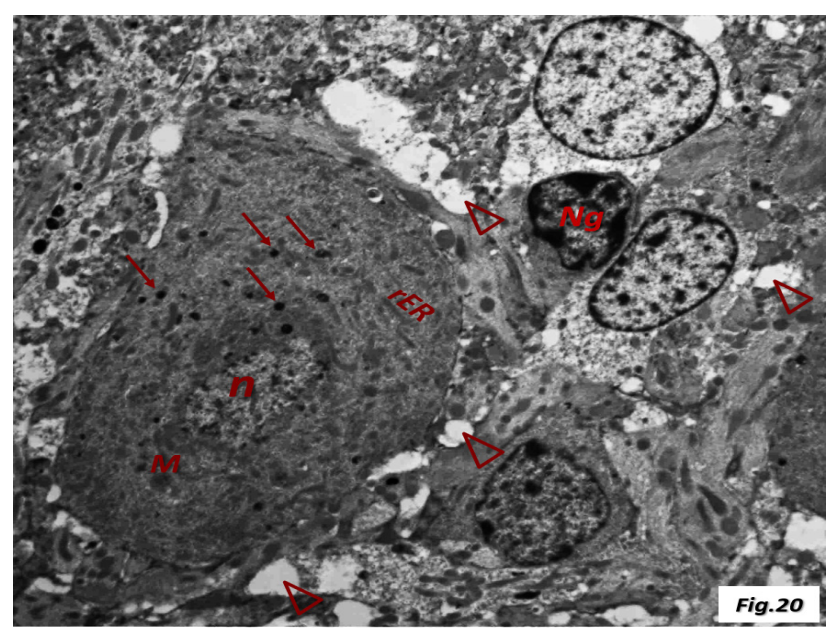

Fig. 20: A photomicrograph of a section of the cerebellar cortex of group III albino rat showing Purkinje neuron with a more electron dense cytoplasm, studded with dark rounded lysosomes $(\uparrow)$, few mitochondria (M), rER (rER), and an almost autolyzed pyknotic nucleus (n). Notice the vacuolar spaces $(\Delta)$ surrounding Purkinje neuron and the others dispersed in the interstitial tissue. Note also the intervening neuroglial cell $(\mathrm{Ng})$. (TEM x1000)

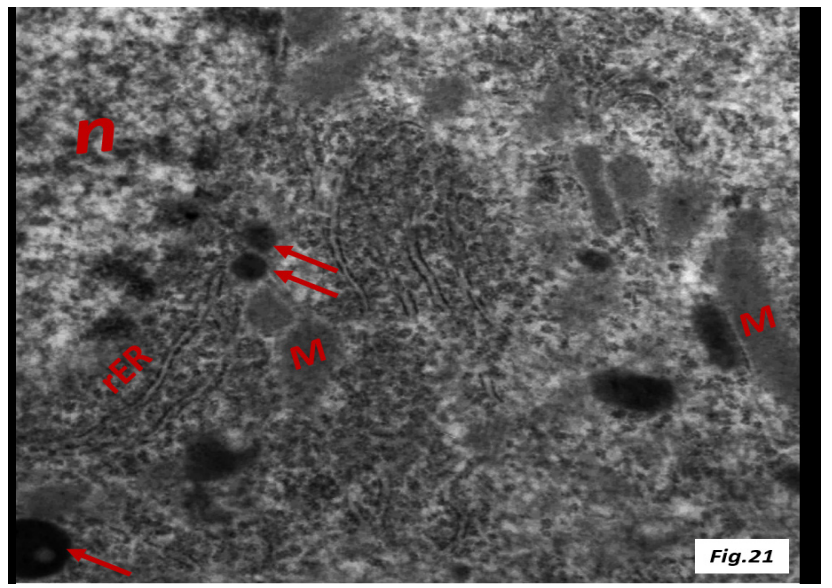

Fig. 21: A photomicrograph of a section of the cerebellar cortex of group III albino rat showing Purkinje neuronal cytoplasm containing dark rounded lysosomes $(\uparrow)$, mitochondria $(\mathrm{M}), \mathrm{rER}(\mathrm{rER})$ and part of the nucleus (n). (TEM x7500)

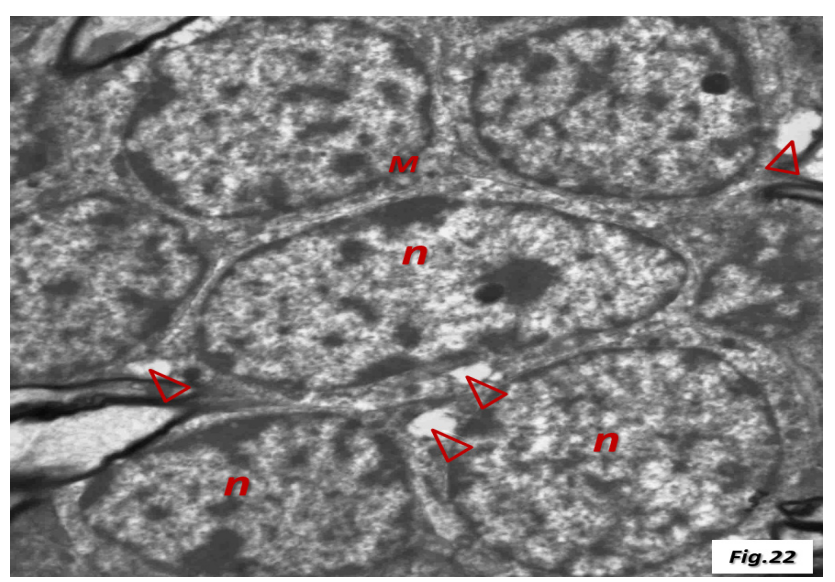

Fig. 22: A photomicrograph of a section of the cerebellar cortex of group III albino rat showing granular neurons with heterochromatic nuclei (n) mitochondria with ruptured cristae $(\mathrm{M})$ and intracellular vacuolar spaces $(\Delta)$. (TEM x2000)

\section{DISCUSSION}

Formaldehyde induced hazards has become a global subject of interest in research nowadays due to its wide use both in the outdoor atmosphere, indoor one as well as its occupational exposure which has become inevitable among medical field workers and industrial ones. Thus there is an increased concern regarding its potential health induced problems especially its neurological hazards.

The cerebellum, being is an important member of the central nervous system family participating in the integration of sensory perception, coordination and motor control, thus its affection might lead to obvious neurological problems ${ }^{[14]}$. There is also increasing evidence that the cerebellum is involved in cognition and emotion in humans ${ }^{[15]}$. Additionally, Hoppenbrouwers et al. (2008) suggested that cerebellum is involved in the pathophysiology of several psychiatric disorders such as autism, schizophrenia, mood and anxiety disorders ${ }^{[16]}$.

The present study revealed marked histopathological affection of rat cerebellar cortex following four weeks 
exposure to FA inhalation. The three cortical layers showed signs of affection which were however more marked and severe in the Purkinje cell one. Molecular layer showed a highly significant decrease in thickness. Its cells exhibited plenty of pyknotic nuclei surrounded by vacuolated rims. Purkinje neurons were mostly shrunken with a highly significant decrease in diameter, mostly distorted, deeply stained and surrounded by empty neuropils and showed reduction in Nissil's granules. This picture was further reinforced by the cytoskeletal disorganization noticed in the electron microscopic examination where Purkinje neurons also appeared shrunken with crenated cell membrane having filiform appendages. Cytoplasm appeared obviously more electron dense compared to the control group with marked degenerative signs. Nucleus also appeared markedly irregular with crenated nucleolemma with disturbance in chromatin distribution.

Appearance of dark neurons had been explained by Ratan et al., (1994) as a reflection of a certain phase of apoptosis as they displayed markedly condensed cytoplasm and nucleoplasm ${ }^{[17]}$. However, other authors believed that existence of dark small neurons was usually ischemic due to possible substantial abnormalities in the capillary wall of the cerebellar cortex with subsequent disorders in the structural elements of the blood-brain barrier to neurons ${ }^{[18]}$.

Moreover, the present study also revealed many ultrastructural degenerative changes within the Purkinje cells including; mitochondria with ruptured cristae, markedly dilated, irregularly arranged cisterns of rER with sparsely distributed ribosomal granules and many intracytoplasmic vacuolar spaces, which might be a result of the disintegration of the dilated rER channels. However, these changes were also encountered within Purkinje cells in the course of chronic experimental intoxication with ethanol ${ }^{[19]}$, sodium fluoride administration ${ }^{[20]}$ as well as long term sodium valproate administration and were considered to be secondary to direct toxicity on neuronal cells that induced profound disorder of intercellular biochemical events, such as inhibition of oxidative phosphorylation, abnormal production of proteins, and dysfunction in the detoxication process ${ }^{[18]}$.

Destructed mitochondrial cristae has been found to be a leading sign of necrotic cell death ${ }^{[21]}$ as it is usually followed by depletion of energy production, with subsequent release of proapoptotic proteins leading to activation of enzymes such as lipases, proteases, and endonucleases ending up with DNA fragmentation ${ }^{[22,23]}$. Additionally; dilation of the endoplasmic reticulum rules out the possibility of cell death especially if associated with swelling of mitochondria and disruption of its internal morphology ${ }^{[24]}$.

As regards the empty neuropils of Purkinje neurons frequently observed in the current work, Sobaniec Lotowska (2001) denoted that this finding could be attributed to the shrinkage of Purkinje cells and withdrawal of their processes secondary to cytoskeletal affection and leaving empty pericellular spaces ${ }^{[18]}$.
However, FA induced Purkinje cell layer pathology was not only confined to neuronal histomorphological changes but extended to reveal multiple focal areas of complete absence of Purkinje neurons leaving only empty neuropils behind. Previous literature stated that, the typical response of most neurons to axonal injury is a cell body reaction involving a complex sequence of molecular and genetic changes that initially sustain compensatory and regenerative responses, but eventually become regressive leading to atrophy or cell death ${ }^{[25]}$. It was suggested that the observed lesions of Purkinje cells in the present work, might affect their functions, with subsequent disturbance in the cerebellar functions. Moreover, Being the prime relay neurons of the cerebellum, Purkinje cell plays a pivotal role in motor coordination and learning and its loss was considered as one of the leading causes in various motor disorders including autism, ataxia and Huntington's disease $\mathrm{e}^{[26-28]}$.

Examination of the granular cell layer revealed clumping of cells together with multiple areas of focal decrease in thickness which was further clarified with morphometric analysis which proved a highly significant decrease in thickness. Ultrastructural damage was additionally observed where many granular cells with pyknotic nuclei surrounded by a shell of cytoplasm with scanty organelles were noted. Bekheeta et al., (2010) similarly observed groups of fused granular cells following morphine sulphate administration producing eosinophilic sheets and stated that it revealed clear coagulative necrosis ${ }^{[29]}$.

The present work also revealed an apparent increase in neuroglial cells especially in the vicinity of the degenerated Purkinje neurons in both the exposure and recovery group rats. In the healthy and resting condition, glial cells normally exist as supportive cells with additional various functions ranging from the regulation of innate immunity, scavenging dead cell debris, scaffolding and protecting neurons to the regulation and maintenance of synaptic transmission and putative integration of information with neurons ${ }^{[30]}$. Following any brain insult or immune breaching, glial cells get activated and exhibit morphological transformations from resting to activated, increase in their cell population and secrete an array of inflammatory molecules ${ }^{[31]}$. Activated microglia are mainly scavenger cells but also perform various other functions in tissue repair, neural regeneration and induction of immune responses. Glial activation based on the progression of insult and severity of stimulus, imposes both beneficial ${ }^{[32]}$ and detrimental effects ${ }^{[33]}$ upon the brain cells.

Glial cell activation may also sustain a chronic inflammation with release of extracellular toxic reactive oxygen and nitrogen species leading to neuronal dysfunction and eventually cell death. Thus, upon activation, these cells may transform into potentially cytotoxic ones ${ }^{[30]}$.

Unfortunately, after FA exposure for a period of four weeks and its withdrawal thus giving the rats a similar period to recover. The results of the present work revealed 
that some histopathological signs showed some degree of improvement while many others did not, revealing persistent affection of cerebellar cortex. Molecular layer still exhibited some pyknotic nuclei. Purkinje cell layer was irregularly aligned with some areas of persistent focal loss with neighboring ones showing multi-layered cells. Afifi (2009) noted similar disrupted Purkinje cell arrangement following sodium fluoride administration where some disappeared completely while in other areas exhibited multilayer accumulation and attributed this to displacement from some areas to be accumulated in others ${ }^{[20]}$.

However, Purkinje cell morphology varied widely in this group both in shape and size where many were still irregular, shrunken and deeply stained while others appeared rarefied with almost complete degeneration in association with normal ones. This variability might denote persistence of degenerative effects together with attempts of recovery. Electron microscopic examination further clarified variability in the Purkinje neuronal ultrastructure where shrunken cells with electron dense cytoplasm, pyknotic nuclei and organelles with degenerative sign still persisted. However, almost regular cells with less electron dense cytoplasm, regular heterochromatic nuclei, some vacuolated mitochondria were also observed. Regarding neuropils, empty pericellular spaces were seen surrounding many Purkinje cells and additional vacuolar spaces were seen dispersed in the interstitial tissue.

Formaldehyde causes activation of free-radicalproducing enzymes and inhibition of antioxidant systems, with subsequent increase in reactive oxygen species (ROS) production leading to damage of biomolecules, including membrane lipids, proteins, and nucleic acids ${ }^{[34]}$. Having a higher content of readily peroxidizable unsaturated fatty acids in cell membranes, CNS is easily attacked by ROS, resulting in the peroxidation of lipids and impairing membrane fluidity and cell structure ${ }^{[35]}$ thus causing many morphological changes in rat brains ${ }^{[36]}$. Therefore, in situations in which the generation of free radicals exceeds the capacity of antioxidant defense, oxidative stress may lead to membrane degradation, cellular dysfunction, and also apoptosis ${ }^{[37]}$. This might explain the persistence of some FA induced degenerative neurons together with attempts of recovery leading to almost back to normal neighboring neurons.

Therefore, exposure to FA inhalation can cause irreversible damage to cerebellar cortical tissue.

\section{CONCLUSION:}

Exposure to Formaldehyde inhalation has been found to cause irreversible damage to cerebellar cortical structure. These results should be taken seriously in order to protect industrial and medical field workers from possible FA induced cerebellar related hazards. However, future researches are required to be conducted on these occupationally exposed persons.

\section{REFERENCES:}

1. Inci M, Zararsız İ, Davarcı M and Görür S (2013): Toxic effects of formaldehyde on the urinary system. Turk. J. Urol. Mar; 39(1):48-52.

2. Golden R (2011): Identifying an indoor air exposure limit for formaldehyde considering both irritation and cancer hazards. Critical Reviews in Toxicology 41: 672-721.

3. Guo X, Johnson RC, Deng H, Liao J, Guan L, Nelson GW, Tang M, Zheng Y, de The G, O’Brien SJ, Winkler CA and Zeng Y (2009): Evaluation of non-viral risk factors for nasopharyngeal carcinoma in a high-risk population of Southern China. International Journal of Cancer 124: 2942 2947.

4. Coggon D, Ntani G, Harris EC and Palmer KT (2014): Upper airways cancer, myeloid leukemia and other cancers in a cohort of British chemical workers exposed to formaldehyde. American Journal of Epidemiology 179: 1301-1311.

5. Metz B, Kersten GF, Hoogerhout P, Brugghe HF, Timmermans HA, de Jong A, Meiring H, ten Hove J, Hennink WE, Crommelin DJ and Jiskoot W (2004): Identification of formaldehyde-induced modifications in proteins: reactions with model peptides. J. Biol. Chem.; 279:6235-6243.

6. Nielsen GD, Larsen ST and Wolkoff P (2013): Recent trend in risk assessment of formaldehyde exposures from indoor air. Archives of Toxicology 87: 73-98.

7. Wang XL, Yuan FS and Zhang ZH (2008): Effect of formaldehyde inhalation on mice's learning and memory. J. Environ. Health 25: 400-402.

8. Doss S, Rinnenthal JL, Schmitz-Hübsch T, Brandt AU, Papazoglou S, Lux S, Maul S, Würfel J, Endres M, Klockgether T, Minnerop M and Paul F (2015): Cerebellar neurochemical alterations in spinocerebellar ataxia type 14 appear to include glutathione deficiency. J. Neurol. 262:1927-1935.

9. Stoodley CJ, Valera EM and Schmahmann JD (2012): Functional topography of the cerebellum for motor and cognitive tasks: an fMRI study. Neuroimage (2012) 59:1560-1570.

10. Mohammadi S (2014): Effect of Selenium on Neurotoxicity in Adult Male Mice Exposed to Formaldehyde. Electronic physician Volume 6, Issue 4, October-December 2014

11. Sayed SA, Mahmoud FY, Anwar RI and Abdel Fatah RM (2013): Effect of Formaldehyde Inhalation on the Olfactory Bulb of Adult Rats. Journal of American Science 9: (9). 
12. Drury R and Wallington E (1980): Carleton's Histological Techniques. 5th edition. Oxford University Press. London, New York and Toronto. pp: 183-184.

13. Bancroft JD and Gamble M (2002): Theory and Practice of Histological Techniques. 5th edition. Churchill Livingstone. London, New York and Sydney. pp: 377-694.

14. Schmahmann JD, Weilburg JB and Sherman JC (2007): The neuropsychiatry of the cerebellum insights from the clinic. Cerebellum 6: 254-267.

15. Schutter DJ and van Honk J (2009): The cerebellum in emotion regulation: a repetitive transcranial magnetic stimulation study. Cerebellum 8: 28-34.

16. Hoppenbrouwers SS, Schutter DJ, Fitzgerald PB, Chen R and Daskalakis ZJ (2008): The role of the cerebellum in the pathophysiology and treatment of neuropsychiatric disorders: a review. Brain Research Review 59: 185-200.

17. Ratan RR, Murphy TH and Baraban JM (1994): Oxidative stress induces apoptosis in embryonic cortical neurons. J. Neurochem. Jan: 62(1): 376-379.

18. Sobaniec Lotowska ME (2001): Ultrastructure of Purkinje cell perikarya and their dendritic processes in the rat cerebellar cortex in experimental encephalopathy induced by chronic application of valproate. Int. J. Exp. Pathol. Dec: 82(6):337-348.

19. Oliveira SA, Chuffa LG, Fioruci-Fontanelli BA, Lizarte Neto FS, Tirapelli LF, Oishi JC, Takase LF, Stefanini MA, Martinez M and Martinez FE (2014): Apoptosis of Purkinje and Granular Cells of the Cerebellum Following Chronic Ethanol Intake. Cerebellum Dec: 13 (6):728-38.

20. Afifi OK (2009): Effect of Sodium Fluoride on the Cerebellar Cortex of Adult Albino Rats and the Possible Protective Role of Vitamin B6: A Light and Electron Microscopic Study. Egypt. J. Histol. Dec. Vol. 32, No. 2: 358 - 367

21. Dambska M and Gajkowska B (2002): Hypoxic damage of the cerebellum in 7-day-old rats. Ultrastructural and histochemical study. Acta Neurobiol. Exp. (Wars) 62(1):45-9.

22. Gajkowska B, Motyl T, Olszewska-Bdarczuk H, Gniadecki R and Koronkiewicz M (2000): Structural association of Bax with nuclear matrix and cytomatrix revealed by embedment-free immunogold electron microscopy. Cell Biol. Monogr. 24: 649-656.

23. Motyl T, Gajkowska B, Poszaj T, Wareski P, Skierski J and Zimowska W (2000): Expression and subcellular redistribution of Bax during TGF B1-induced programmed cell death of $\mathrm{HC} 11$ mouse mammary epithelial cells. Cell. Mol. Biol. 46: $175-185$.

24. Cheng G, Shi Y, Sturla SJ, Jalas JR, McIntee EJ, Villalta PW, Wang M and Hecht SS (2003): Reactions of formaldehyde plus acetaldehyde with deoxyguanosine and DNA: formation of cyclic deoxyguanosine adducts and formaldehyde crosslinks. Chem. Res. Toxicol. 16: 145-152.

25. Rossi F, Gianola S and Corvetti L (2006): The strange case of Purkinje axon regeneration and plasticity. Cerebellum. 5(2):174-182.

26. Whitney ER, Kemper TL, Bauman ML, Rosene DL and Blatt GJ (2008): Cerebellar Purkinje cells are reduced in a subpopulation of autistic brains: a stereological experiment using cal bind in-D28k. Cerebellum 7: 406-416.

27. Matilla-Dueñas A, Corral-Juan M, Volpini V and Sanchez I (2012): The Spinocerebellar ataxias: clinical aspects and molecular genetics. Neurodegenerative Diseases 351-374.

28. Rüb U, Hoche F, Brunt ER, Heinsen H, Seidel K, Del Turco D, Bohl J, von Gall C, Vonsattel JP, Korf HW and den Dunnen WF (2013): Degeneration of the cerebellum in Huntington's disease (HD): Possible relevance for the clinical picture and potential gateway to pathological mechanisms of the disease process. Brain Pathol. 23: 165-177.

29. Bekheeta SH, Saker SA, Abdel-Kader AM and Younis AE (2010): Histopathological and biochemical changes of morphine sulphate administration on the cerebellum of albino rats. Tissue and Cell (42):165-175.

30. Vilhardt F (2005): Microglia: Phagocyte and glia cell. Int. J. Biochem. Cell Biol. Jan: 37(1):17-21.

31. Boche D, Perry VH and Nicoll JA (2013): Review: Activation patterns of microglia and their identification in the human brain. Neuropathol. Appl. Neurobiol. 39: 3-18.

32. Luo XG and Chen SD (2012): The changing phenotype of microglia from homeostasis to disease. Transl. Neurodegener. Apr 24:1(1):9.

33. Heneka MT, Rodríguez JJ, and Verkhratsky A (2010): Neuroglia in neurode- generation. Brain. Res. Rev. 63: 189 - 211.

34. Whelan HT, Bajic DM, Karlovits SM, Houle JM, Kindwall EP (1998): Use of cytochrome-P450 mono-oxygenase $2 \mathrm{E} 1$ isozyme inhibitors to delay seizures caused by central nervous system oxygen toxicity. Aviat. Space Environ. Med. 69: 480-485.

35. Datta NJ and Namasivayam A(2003): In vitro effect of methanol on folate-defficient rat hepatocytes. Drug Alcohol Depen. 71: 87-91. 
36. Zararsiz I, Kus I, Ogeturk M, Akpolat N, Kose E, Meydan S and Sarsilmaz M (2007): Melatonin prevents formaldehyde-induced neurotoxicity in prefrontal cortex of rats: an immunohistochemical and biochemical study. Cell Biochem. Funct. 25: 413-418.
37. Halliwell B (2006): Oxidative stress and neurodegeneration: where are we now? J. Neurochem.; 97:1634-1658. 
الملخص العربى

\section{تأثير إستشاق الفورمالديهايد على بنية قشرة المخيخ فى ذكورالجرذان البيضاء البالغه و إحتماليه الإستشفاء \\ مارى رفعت اسحق وشيرين عادل سعد

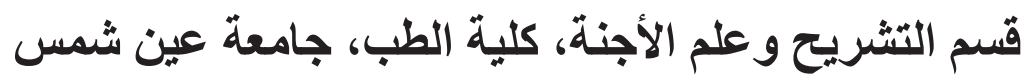

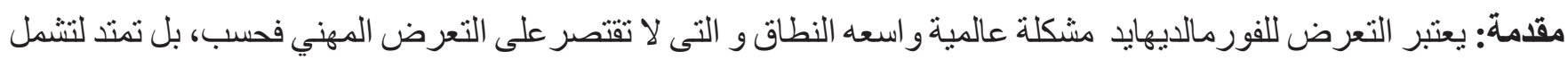

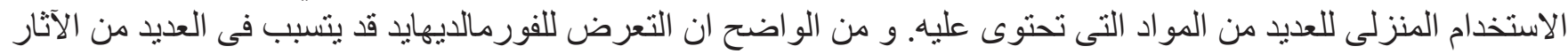

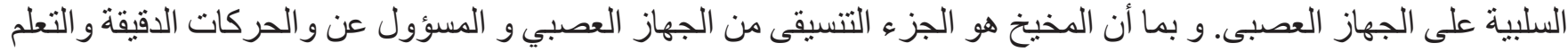

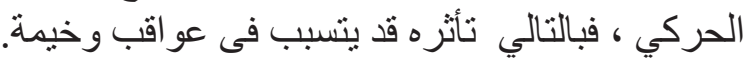

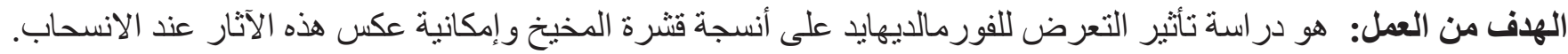

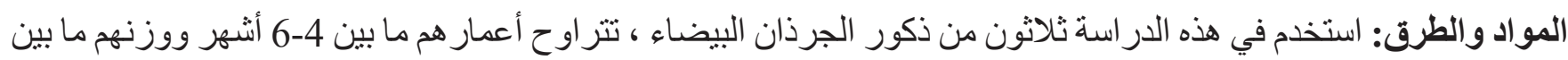

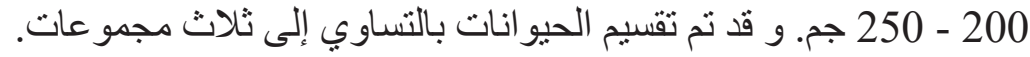
المجمو عة الأولى: المجمو عة الضابطه.

المجمو عة الثانية: خضعت جزنانها لاستنشاق الفورمالديهايد لمدة 8 ساعات يوميا ، 6 أيام / أسبو ع لمدة أربعة أسابيع.

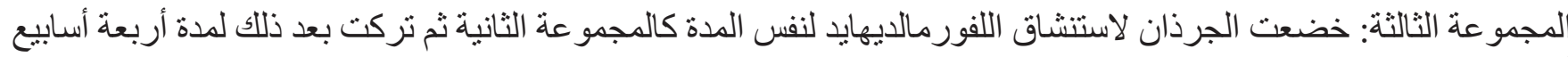

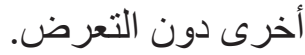
في نهاية التجربة لكل مجمو عة ، تم جمع العينات ومعالجتها من أجل الفحص بالمجهرين بلضوئى و الإلكترونى بالاضافه الى عمل در اسات مورفومترية.

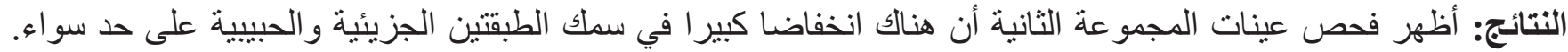

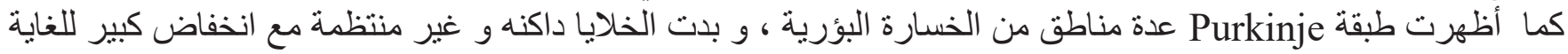

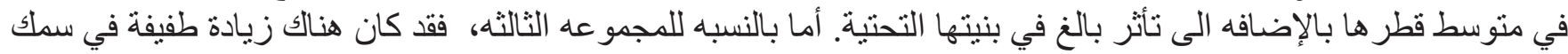

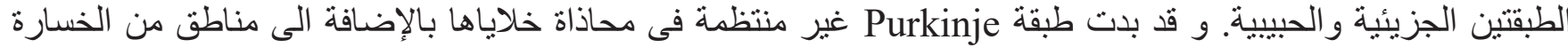

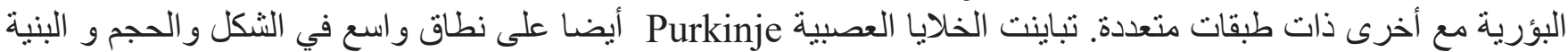

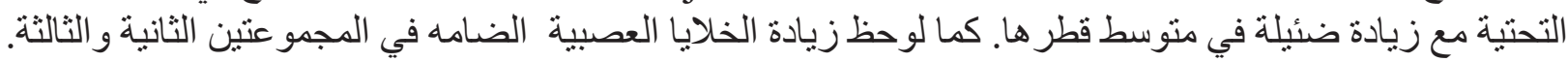

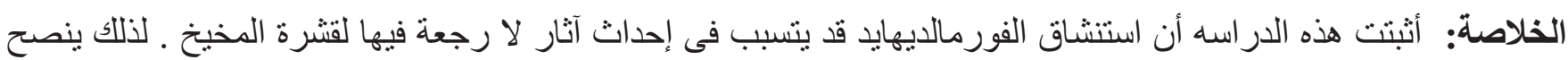

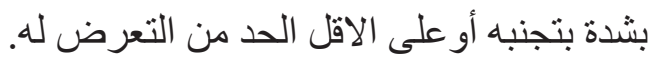

